Creative Commons User License: CC BY-NC-ND

Journal of Agricultural Extension

Abstracted by: EBSCOhost, Electronic Journals Service (EJS), Vol. 23 (1) January, 2019

Google Scholar, Journal Seek, Scientific Commons,

Food and Agricultural Organization (FAO), CABI and Scopus

http://eoi.citefactor.org/10.11226/v23i1
ISSN(e): 24086851; ISSN(Print); 1119944X

http://journal.aesonnigeria.org

http://www.ajol.info/index.php/iae

Email: editorinchief@aesonnigeria.org

\title{
Farmers' Adjustment to Dwindling Services of the Public Extension System in Enugu State, Nigeria \\ https://dx.doi.org/10.4314/jae.v23i1.13
}

\section{Nwobodo, Cynthia E.}

Department of Agricultural Extension, University of Nigeria, Nsukka. Enugu State, Nigeria

Email: cynthia.nwobodo@unn.edu.ng

Phone no: 08039462574.

\section{Agbo, Chinenye M.}

Department of Agricultural Extension, University of Nigeria, Nsukka.Enugu State, Nigeria Email: chinenye.agbo.184002@unn.edu.ng

Phone: 07061032514

\section{Ohagwu, Violet A.}

Department of Agricultural Extension, University of Nigeria, Nsukka. Enugu State, Nigeria

Email:violet.ohagwu@unn.edu.ng

Phone no: 08134960506

\section{Igbokwe, Edwin M.}

Department of Agricultural Extension, University of Nigeria, Nsukka. Enugu State, Nigeria

Email:edwin.igbokwe@unn.edu.ng

Phone:08034261915.

\section{Abstract}

The study investigated farmers' adjustment to dwindling public extension services in Enugu State, Nigeria. Multistage sampling technique was used to select ninety-six (96) respondents from three agricultural zones in the study area, data were collected through the use of semi-structured interview schedule. Percentage, frequency and mean scores were the statistical tools used for data analysis. The majority (64.6\%) of the respondents adjusted by developing stronger management skill. Findings revealed that all (100\%) the respondents adjusted in information source by sourcing agricultural information from personal experience. Findings showed that the majority $(97.9 \%)$ adjusted in sources of finance and credits by using self-financing. The majority of the respondents (76.0\%) preferred self-financing as their source of finance and credit coming from their savings. Results showed that the majority (97.9\%) of the respondents made finance/credit adjustment by increased saving for future. use It is necessary to facilitate farmer-to-farmer extension linkage to help farmers keep abreast of necessary information that will 
Creative Commons User License: CC BY-NC-ND

Abstracted by: EBSCOhost, Electronic Journals Service (EJS)

Google Scholar, Journal Seek, Scientific Commons,

Food and Agricultural Organization (FAO), CABI and Scopus

http://eoi.citefactor.org/10.11226/v23i1
Journal of Agricultural Extension

Vol. 23 (1) January, 2019

ISSN(e): 24086851; ISSN(Print); 1119944X

http://journal.aesonnigeria.org

http://www.ajol.info/index.php/iae

Email: editorinchief@aesonnigeria.org

enhance production, help them develop more management skill so that they can feed their families and improve their standard of living. Financial institutions should provide loan to farmers at $30 \%$ interest rate.

Key words: farmers' adjustments, public extension,

\section{Introduction}

Agriculture in Nigeria is considered as the background of the country's economy even during the 'oil boom' era. According to Central Intelligence Agency World Fact Book (2016), it stated that following an April 2014 statistical "rebasing" exercise, Nigeria emerged as Africa's largest economy, with 2013 GDP estimated at US $\$ 502$ billion. However, the GDP growth of Nigeria recently is very sluggish because of the continued fall in oil prices and the slowdown in production in some other sectors of the economy (Asogwa and Barungi et.al., 2016). Nigeria's real Gross Domestic Product (GDP) growth rate declined to -0.36 per cent in the first quarter of 2016 (Q1 2016) compared to 2.11 per cent in Q4 of 2015 (Muhammad and Agabi,2016)

The Agricultural Development Programme (ADP) has being the major government establishment charged with the responsibility of providing extension service to farmers; the ADP is the extension arm of the Ministry of Agriculture with its presence in all the state of the federation. It adopts the training and visit (T\&V) system in it approach to reaching out to its clientele. The ADP does not engage in direct food production, rather they provide services and infrastructures, while the farmers do the production. With the withdrawal of the World Bank which is the major sponsor of agricultural development programme in Nigeria, and with the unsteady nature of Nigerian economy, ADPs in Nigeria have not been functioning efficiently. When the country has no money, the federal and state government funding contributions for ADPs decreases and consequently, the ADPs will adjust by reducing the number of extension workers thereby reducing the number and frequency of visits and services received by farmers.

With the dwindling national income, most agricultural programmes are bound to be impacted negatively. Consequently, most states are unable to pay salaries and other emolument to public officers including extension agents. The result is that farmers receive little or no visit from extension agents. However, farmers need to keep abreast of necessary information that will enhance cultivation and be well aware of issues and developments surrounding any crop and livestock before every farming season as they are actively involved in feeding the nation and sustaining industries (Sokoya, Adefunke and Fagbola, (2014). Farmers also need to feed their families and improve their standard of living and as such when the ADPs fail to meet up with their need, they look for an alternative means to get the necessary agricultural information and inputs.

The questions that arise are: Who are the current players in agricultural extension services in Nigeria? What production adjustments have farmers made in response to poor extension services? What knowledge/ information adjustments have taken places in terms of sources? What are the adjustments in terms of sources of finances and credits? 
Creative Commons User License: CC BY-NC-ND

Abstracted by: EBSCOhost, Electronic Journals Service (EJS),

Google Scholar, Journal Seek, Scientific Commons,

Food and Agricultural Organization (FAO), CABI and Scopus

http://eoi.citefactor.org/10.11226/v23i1
Journal of Agricultural Extension

Vol. 23 (1) January, 2019

ISSN(e): 24086851; ISSN(Print); 1119944X

http://journal.aesonnigeria.org

http://www.ajol.info/index.php/jae

Email: editorinchief@aesonnigeria.org

\section{Purpose of the Study}

The overall purpose of the study was to ascertain the level of farmers' adjustment to public extension services in a contracted economy in Enugu State, Nigeria. Specifically, the study sought to:

- examine the socio-economic characteristics of the respondents;

- identify production adjustments in response to dwindling public extension services;

- ascertain knowledge (information) adjustments farmers have made in response to dwindling public extension services; and

- Identify adjustments in sources of finances and credits.

\section{Methodology}

The population of the study comprised all farmers in Enugu State, Nigeria. Multistage sampling technique was used in selecting respondents for the study. At the first stage, three (3) agricultural zones (Nsukka, Enugu-Ezike and Udi) out of the six agricultural zones in the State were selected using simple random sampling technique. At the second stage, two (2) blocks were selected, using simple random technique, from each of the three zones giving a total of six (6) blocks. The selected blocks were Nsukka and Uzouwani (Nsukka zone), IgboEze North and Udenu(Enugu-Ezike Zone), Ezeagu and Udi (Udi zone). At the third stage, two (2) cells were selected from eachblock using simple random sampling technique to give a total of 12 cells. The selected cells were:Nsukka, and Ede-Oballa(Nsukka Block); Adani and Opanda(Uzouwani Block); Ekposhi, and Umuida (Igbo-Eze North Block); Obollo-Eke and Obollo-Etiti (Udenu Block); Agbaumana and Umanandiagu (Ezeagu Block); Umuaga andUmabi (Udi Block). At the fourth stage, eight (8) farmers were selected from a list of farmers in each cell using simple random sampling technique. Thus, the total sample size for the study was ninety-six (96) respondents.

Socio-economic characteristics of respondents were collected at nominal and interval level. Respondents were asked to indicate their age (years), sex (male or female), marital status (single, married, widowed, divorced, separated), educational status (no formal education, primary school attempted, primary school completed, secondary school attempted, secondary school completed, tertiary education), type of farming (crop farming, livestock, livestock/mixed cropping, fisheries), annual income (in naira) and extension contact. Production adjustments farmers had made in response to dwindling public extension services were collected by asking them to tick Yes $=1$ or $\mathrm{No}=0$ to indicate their response to a set of questions provided such as reduction of enterprise, developing stronger management skills, having direct contact with research, etc. Knowledge (information) adjustments were collected by asking respondents to tick yes $=1$ or no $=0$ to the appropriate sources and also to tick on a five-point Liker-type scale to indicate their frequency of access to the sources of information. The mean/cut-off point was 3 . Finances and credits adjustments were collected by asking respondents to tick $\mathrm{Yes}=1$ or $\mathrm{No}=0$ from a list of entry categories provided on sources of finance and credit which include; family/relatives, commercial banks, money lenders, self-financing etc. and adjustments made in finances and credits which include; reduced borrowing, increased borrowing, increased saving for 
Creative Commons User License: CC BY-NC-ND

Abstracted by: EBSCOhost, Electronic Journals Service (EJS)

Google Scholar, Journal Seek, Scientific Commons,

Food and Agricultural Organization (FAO), CABI and Scopus

http://eoi.citefactor.org/10.11226/v23i1
Journal of Agricultural Extension

Vol. 23 (1) January, 2019

ISSN(e): 24086851; ISSN(Print); 1119944X

http://journal.aesonnigeria.org

http://www.ajol.info/index.php/iae

Email: editorinchief@aesonnigeria.org

future use etc. and the respondents were also required to indicate their most preferred source of finance. Data were presented using descriptive statistics.

\section{Results and Discussions}

\section{Socio-Economic Characteristics of Respondents}

Table 1 shows that a greater proportion (32.2\%) of the respondents was of the age range of 31-40 years. The mean age of the respondents was 42.82 years. This shows that the respondents are still in their active and productive age and can actively adjust to dwindling public extension services. This finding agrees with Nzeh, Akogwu and Ugwu et.al (2014) who also found out that $36.6 \%$ of cocoyam farmers in Enugu state were within the age range of $41-50$ years. Findings also reveal that greater proportions of the respondents $(49.5 \%)$ were male and the majority $(83.8 \%)$ of the respondents were married. These show that the gender roles in agricultural production can be effectively distributed among the men and women so as to adjust to dwindling public extension services in Enugu state. This finding agrees with Chah, Irohibe and Itodo et.al (2015) who found that the majority (67.0\%) of the respondents in Enugu state were married and hence, they are likely to have labour for poultry production activities.

Table 1 further show that a greater proportion (33.3\%) of the respondents completed primary school education. The majority $(65.7 \%)$ of respondents engaged in both livestock and crop production. This shows that respondents were engaged in livelihood diversification which will help them bear possible risk to their farm activities This finding is in line with that of Mgbakor, Uzendu and Ndubisi (2014) that $60 \%$ of small-scale farmers in Ezeagu Local Government area of Enugu state engaged in crop production and small scale animal production.

Entries in Table 1 also show that the greater proportion (23.1\%) had estimated annual income of $\mathrm{N} 200,000-\mathrm{N} 400,000$. The mean estimated annual income was N73, 0078.12. Table 1 shows that only $24.2 \%$ of the respondents ever had extension contact out of which $5.0 \%, 4.0 \%$ and $1.0 \%$ had the contact twice, once and three times respectively in the last one year. The mean number of times of visitation is 1.7 . This result reveals that about $72.7 \%$ did not have any extension contact, which means that agricultural extension is not living up to expectation in the area and as a result, farmers had to find an alternative means of adjusting to the insufficient and inadequate extension visit. This is in line with the finding of Abugu, Chah and Nwobodo (2013) that $63 \%$ of Telfairia farmers in Enugu state did not have extension contact in the last one year which could result in poor access to relevant information on how to improve Telfairia production and marketing. Agbo, Iroh and Ihemezie (2015) stated that the majority (57.4\%) of the sampled vegetable farmers in Owerri agricultural zone of Imo State had no contact with agricultural extension services or personnel and that it may have hindered their access to improved technologies in vegetable production. 
Creative Commons User License: CC BY-NC-ND

Abstracted by: EBSCOhost, Electronic Journals Service (EJS), Google Scholar, Journal Seek, Scientific Commons,

Food and Agricultural Organization (FAO), CABI and Scopus

http://eoi.citefactor.org/10.11226/v23i1
Journal of Agricultural Extension

Vol. 23 (1) January, 2019

ISSN(e): 24086851; ISSN(Print); 1119944X

http://journal.aesonnigeria.org

http://www.ajol.info/index.php/jae

Email: editorinchief@aesonnigeria.org

Table 1: Socio-economic characteristics

\begin{tabular}{|c|c|c|}
\hline Variables & $\begin{array}{l}\text { Percenta } \\
\text { ge }\end{array}$ & Mean \\
\hline \multicolumn{3}{|l|}{ Age } \\
\hline Less than/ equal to 30 & 18.1 & \\
\hline $31-40$ & 32.2 & 42.8 \\
\hline $41-50$ & 29.2 & \\
\hline $51-60$ & 7.0 & \\
\hline 61 and above & 10 & \\
\hline \multicolumn{3}{|l|}{ Sex } \\
\hline Male & 49.5 & \\
\hline Female & 47.5 & \\
\hline \multicolumn{3}{|l|}{ Marital status } \\
\hline Single & 8.1 & \\
\hline Married & 83.8 & \\
\hline Widowed & 4.0 & \\
\hline Separated & 1.0 & \\
\hline \multicolumn{3}{|l|}{ Educational level } \\
\hline No formal education & 6.1 & \\
\hline Primary school attempted & 5.1 & \\
\hline Primary school completed & 33.3 & 8.7 \\
\hline Secondary school attempted & 15.2 & \\
\hline Secondary school completed & 26.3 & \\
\hline Tertiary education & 11.1 & \\
\hline \multicolumn{3}{|l|}{ Type of farming enterprise } \\
\hline Crop farming & 31.3 & \\
\hline Livestock & - & \\
\hline Livestock/crop mixed & 65.7 & \\
\hline Fisheries & 1.0 & \\
\hline \multicolumn{3}{|c|}{$\begin{array}{l}\text { Estimated household annual income from farm } \\
\text { activities }\end{array}$} \\
\hline Less than 200,000 & 21.1 & \\
\hline $200,000-400,000$ & 23.1 & 7300 \\
\hline $400,001-600,000$ & 18.2 & 78.1 \\
\hline $600,001-800,000$ & 8.1 & \\
\hline $800,001-100,000$ & 12.2 & \\
\hline Above 100,000 & 14.0 & \\
\hline \multicolumn{3}{|l|}{ Extension visit } \\
\hline Yes & 24.2 & \\
\hline \multicolumn{3}{|c|}{ Number of times visited in the past one year (2016) } \\
\hline 1 & 4.0 & \\
\hline 2 & 5.1 & 1.7 \\
\hline 3 & 1.0 & \\
\hline
\end{tabular}


Creative Commons User License: CC BY-NC-ND

Abstracted by: EBSCOhost, Electronic Journals Service (EJS)

Google Scholar, Journal Seek, Scientific Commons,

Food and Agricultural Organization (FAO), CABI and Scopus
Journal of Agricultural Extension

Vol. 23 (1) January, 2019

ISSN(e): 24086851; ISSN(Print); 1119944X

http://journal.aesonnigeria.org

http://www.ajol.info/index.php/iae

Email: editorinchief@aesonnigeria.org

http://eoi.citefactor.org/10.11226/v23i1

\section{Production Adjustments to Dwindling Extension Services}

Table 2 shows that $85.4 \%$ of the respondents adjusted in production as the majority $(64.6 \%)$ of the respondents adjusted in production by developing stronger management skill, while $51.0 \%$ adjusted by diversification of livelihood activities. These results imply that the respondents should be given more support by government in terms of providing them with opportunities to acquire more skills to enable them increase and manage their production more efficiently. It can also be inferred that most of the farmers in the area are slowly leaving agriculture as about $51.0 \%$ adjusted in production by diversifying their livelihood activities. Hence, these farmers can be encouraged if agriculture is made to be more lucrative/attractive.

Similarly, $42.7 \%$ adjusted in production by adoption of mixed cropping, and $41.7 \%$ adjusted by reducing post-harvest losses. Others include changing to crop varieties and animals that have higher yield (35.4\%), increased productivity (34.45\%). They also seek alternative sustainable financing (13.5\%) and reduction of enterprise $(11.5 \%)$, engagement in contract farming (10.45\%) and having direct contact with research (6.3\%). The result also shows that research is not very effective in the area as only $6.3 \%$ of the farmers had direct contact with research.

This finding agrees with that of Christiaensen, (2017) that although, farming activities remain crucial, rural dwellers often look for diverse opportunities to increase and stabilize their income for long term sustainable livelihood and improved welfare. Most of the respondents also adjusted in production by adopting mixed cropping technique and reducing postharvest losses such as drying loss, winnowing loss, storage loss, transportation loss, milling loss etc. in any way that is within their capacity. The work of Sanzidur and Chidiebere (2016) revealed that farmers in south eastern Nigeria grow multiple crops instead of single crop.

\section{Table 2: Production adjustments of respondents}

\begin{tabular}{ll}
\hline Variables & Percentage \\
\hline Made any production adjustment & \\
Yes & 85.4 \\
Areas of adjustments & \\
Reduction of enterprise & 11.5 \\
Increased productivity & 34.4 \\
Education of farmers & 1.0 \\
Developing stronger management skill & 64.6 \\
Establishing direct contact with research & 6.3 \\
Seek alternative sustainable financing & 13.5 \\
Change type of crop cultivated & 1.0 \\
Change from crop to animal production & - \\
Change from animal to crop production & - \\
Change to higher yielding varieties of crops and animals & 35.4 \\
Engagement in contract farming & 10.4 \\
Diversification of livelihood activities & 51.0 \\
Adoption of mixed cropping & 42.7 \\
Adoption of mixed farming & 2.1 \\
\hline
\end{tabular}


Creative Commons User License: CC BY-NC-ND

Abstracted by: EBSCOhost, Electronic Journals Service (EJS)

Google Scholar, Journal Seek, Scientific Commons,

Food and Agricultural Organization (FAO), CABI and Scopus
Journal of Agricultural Extension

Vol. 23 (1) January, 2019

ISSN(e): 24086851; ISSN(Print); 1119944X

http://journal.aesonnigeria.org

http://www.ajol.info/index.php/iae

Email: editorinchief@aesonnigeria.org

http://eoi.citefactor.org/10.11226/v23i1

\section{Information Source for Adjustments to Dwindling Extension Services}

Table 3 shows that $100 \%$ of the respondents adjusted in information sourcing by obtaining agricultural information from personal experience, while $93.8 \%$ adjusted by sourcing from family/relatives. The implication of these results is that the respondents carry out their dayto-day farm activities with knowledge from their personal experience and family members which means that they may not be getting optimum production as they stick to the old practices they had known over the years and those transmitted to them from family members; so, these farmers should be encouraged to seek out modern practices that can help them to obtain optimum yield.

Similarly, $87.5 \%$ and $52.1 \%$ adjusted by sourcing their agricultural information from fellow farmers/friends and radio respectively. Others include agricultural input suppliers (47.9\%), television (21.9\%), farmer association (18.35\%), religious organization $(16.7 \%)$, mobile phone (11.5\%), print media (10.4\%), village leaders (10.4\%), Internet (8.3\%) and International development organizations (6.3\%). The proportion of farmers that sourced from internets was small, indicating low literacy level of the respondents. Also, only $10.4 \%$ sourced from print media showing that it is either that the print media is expensive to buy or that it requires high skill to access as greater proportion of the respondents completed only primary school. The finding is consistent with that of Ifeanyi-Obi and Togun et.al. (2017), who found that the majority of cocoyam farmers in Southeast Nigeria accessed climate change information through their personal experience, and they also stated that use of mobile phones in disseminating climate change information is yet to be harnessed as mobile phone is mainly used as a means of sharing personal information. They found that $29.7 \%$ sourced information from television, $11.7 \%$ got from newspaper and $3.4 \%$ sourced from internet.

Entries in Table 3 also indicate that the respondents frequently accessed agricultural information from personal experience with the mean $(\dot{x}=4.93 ; S D=0.26)$, family/relatives $(M=4.13 ; S D=1.06)$ and fellow farmers/friends $(M=3.53 ; S D=1.21)$. The results show that personal experience is what helps farmers to make tactical planning of their day-to-day management decisions in farm as it is accessed more regularly than others. This corroborates that of Ifeanyi-Obi and Togun et.al. (2017), who found that the majority of cocoyam farmers in Southeast Nigeria accessed climate change information through their personal experience. 
Creative Commons User License: CC BY-NC-ND

Abstracted by: EBSCOhost, Electronic Journals Service (EJS),

Google Scholar, Journal Seek, Scientific Commons,

Food and Agricultural Organization (FAO), CABI and Scopus

http://eoi.citefactor.org/10.11226/v23i1
Journal of Agricultural Extension

Vol. 23 (1) January, 2019

ISSN(e): 24086851; ISSN(Print); 1119944X

http://journal.aesonnigeria.org

http://www.ajol.info/index.php/iae

Email: editorinchief@aesonnigeria.org

Table 3: Knowledge adjustments of respondents

\begin{tabular}{llll} 
Sources of information & Percentage & $\begin{array}{l}\text { Mean number } \\
\text { of times of } \\
\text { access }\end{array}$ & Std. Deviation \\
& & 4.13 & 1.06 \\
\hline Family/relatives & 93.8 & 1.47 & 0.97 \\
Television & 21.9 & 2.53 & 1.63 \\
Radio & 52.1 & 3.53 & 1.21 \\
Fellow farmers/friends & 87.5 & 1.21 & 0.65 \\
Mobile phone & 11.5 & 4.93 & 0.26 \\
Personal experience & 100 & 1.19 & 0.60 \\
Printed media e.g. magazine, & 10.4 & 1.48 & 1.12 \\
newspaper, leaflets etc. & 18.3 & 2.32 & 1.55 \\
Farmers association & 47.9 & 1.26 & 0.68 \\
Agricultural input suppliers & 16.7 & 1.08 & 0.35 \\
Religious organization & 6.3 & 1.19 & 0.60 \\
International development organization & 10.4 & 1.04 & 0.20 \\
Village leaders & 4.2 & 1.21 & 0.75 \\
Libraries & 8.3 & & \\
Internet & & & \\
\hline
\end{tabular}

\section{Adjustments in Sources of Finance}

Table 4 shows that the majority (97.9\%) adjusted in sources of finance and credit by sourcing from self-financing, while $52.1 \%$ sourced from family/relatives, $47.9 \%$ sourced from cooperative societies and $41.7 \%$ sourced from friends/neighbours. These results imply that the respondents do not use sufficient fund for their production and so government should make provision for support funds. This finding is closely related to that of Akinnagbe and Adonu, (2014) who found that small scale farmers in Nsukka Local Government area sourced their agricultural credit from personal savings and friends/relatives (62.5\%). They further found in contrast to this work that co-operative societies accounted for the highest $(84.7 \%)$ source of agricultural credit for the small- scale farmers.

It is important to note that microfinance bank accounted for $3.1 \%$, government accounted for $1.0 \%$ and commercial bank accounted for $1.0 \%$. This could be as a result of high interest on loan, collateral and long loan processing period from banks. Also, loan from government may require long processing periods and may not get to the farmers at the time it is needed for their production. This is in line with the work of Akinnagbe and Adonu (2014) who found that only $3.6 \%$ of the respondents in Nsukka Local Government area of Enugu State sourced credit from commercial banks.

The majority of the respondents $(76.0 \%)$ preferred self-financing as their source of finance and credit, while $13.5 \%$ preferred cooperative societies and $6.3 \%$ preferred family/relatives. This result indicates that personal savings contributed the major bulk of the capital used for agricultural production, followed by the ones contributed by family and friends. This is in line 
Creative Commons User License: CC BY-NC-ND

Abstracted by: EBSCOhost, Electronic Journals Service (EJS),

Google Scholar, Journal Seek, Scientific Commons,

Food and Agricultural Organization (FAO), CABI and Scopus
Journal of Agricultural Extension

Vol. 23 (1) January, 2019

ISSN(e): 24086851; ISSN(Print); 1119944X

http://journal.aesonnigeria.org

http://www.ajol.info/index.php/jae

Email: editorinchief@aesonnigeria.org

with the finding ofAgbo, Iroh and Ihemezie (2015) that the majority of vegetable farmers got their credit source from informal sources which proved to be more successful in meeting the credit needs of the farmers in the study area even though sometimes the credit is limited.

Only $1.0 \%$ each preferred money lender and neighour/friends and this contrasts with the work of Mgbakor, Uzendu and Ndubisi (2014) which revealed that the most available credit source to Ezeagu farmers were through individual money lenders (38\%) and it is closely followed by neighbours and relatives (30\%).

\section{Table 4: Adjustments in sources of finance}

\begin{tabular}{lll}
\hline Finance and credit source & Percentage & $\begin{array}{l}\text { Preferred } \\
\text { sources } \\
(\%)\end{array}$ \\
\hline Family/Relatives & 52.1 & 6.3 \\
Friends/Neighbours & 41.7 & 1.0 \\
Farmer cooperatives /isusu & 5.2 & - \\
Commercial Banks & 1.0 & - \\
Money lenders & 5.2 & 1.0 \\
Corporate societies & 47.9 & 13.5 \\
Self-financing & 97.9 & 76.0 \\
Microfinance Bank & 3.1 & 1.0 \\
Government & 1.0 & - \\
\hline
\end{tabular}

\section{Finance/credit adjustments}

Table 5 shows that the majority (97.9\%) of the respondents made finance/credit adjustment through increased saving for future use, while $82.3 \%$ made adjustment in finance/credit by reducing their borrowing. Others include: increasing number of source of finance/credit $(32.3 \%)$ and increased borrowing (16.7\%). The implication of the result is that the respondents adjusted better in finance/credit through increased saving for future use. The savings are ploughed back into their production and it also shows that they can finance any innovation that can help them to adjust and adapt to the changing public extension service from their personal savings. Saving is also important because it allows you to deal with emergencies and unforeseeable events. This finding agrees with John and Osondu (2015) who opined that personal savings, friends or relatives and co-operative societies, which are non-institutional credit sources are the major sources among farmers in Idemili Local Government Area of Anambra State, as they may require little or no collateral security. 
Creative Commons User License: CC BY-NC-ND

Abstracted by: EBSCOhost, Electronic Journals Service (EJS)

Google Scholar, Journal Seek, Scientific Commons,

Food and Agricultural Organization (FAO), CABI and Scopus

http://eoi.citefactor.org/10.11226/v23i1
Journal of Agricultural Extension

Vol. 23 (1) January, 2019

ISSN(e): 24086851; ISSN(Print); 1119944X

http://journal.aesonnigeria.org

http://www.ajol.info/index.php/iae

Email: editorinchief@aesonnigeria.org

Table 5: Finance adjustment

\begin{tabular}{ll}
\hline Finance/credit adjustment & Percentage \\
\hline Reduced borrowing & 82.3 \\
Increased borrowing & 16.7 \\
Increased saving for future use & 97.9 \\
Increased number of sources of finance/credit & 32.3 \\
\hline
\end{tabular}

\section{Conclusion and Recommendations}

Farmers in Enugu state adjusted in production by developing stronger management skill. All the respondents adjusted in information source by sourcing agricultural information through personal experience. The sources where respondents got agricultural information frequently were: personal experience, family/relatives and fellow farmers/friends. The frequency of access to agricultural information was mainly from personal experience. Also, respondents sourced their finance and credit from self-financing and still preferred self-financing as their major source of finance and credit. They also made finance/credit adjustment by increased saving for future use.

Government should make policy in order to make financial institutions provide loan facilities to farmers at low interest rate and also enhance easier access to loan by farmers. Public extension services should be made available to farmers in Enugu state to facilitate dissemination of appropriate and efficient agricultural information and credit/finance source opportunities. Farmers should be encouraged to form groups and associations that can help to improve their production skills and finances.

Also, it is necessary to facilitate farmer-to-farmer extension linkage to help farmers keep abreast of necessary information that will enhance production, help them develop more management skill so that they can feed their families and improve their standard of living. Government should make provision for incentives and support to farmers in form of credit or loan as these would help to obtain necessary agricultural information and inputs.

\section{References}

Abugu, R. O., Chah, J.M., Nwobodo, C., Asadu, A. N. and Igbokwe, E.M. (2013) Agricultural extension needs of farmers in Telfairia production and marketing in Enugu State, Nigeria. Journal of Agricultural Extension, 17 (1): 4960.http://dx.doi.org/10.4314/jae.v17i1.5Retrieved on 28/08/2017.

Agbo, F.U., Iroh I.I. and Ihemezie, E.J., (2015)Access to credit by vegetable farmers in Nigeria: A case study of Owerri Agricultural Zone of Imo State, Nigeria. Asian Journal of Agricultural Research, 9 (4): 155-165. 
Creative Commons User License: CC BY-NC-ND

Abstracted by: EBSCOhost, Electronic Journals Service (EJS),

Google Scholar, Journal Seek, Scientific Commons,

Food and Agricultural Organization (FAO), CABI and Scopus

http://eoi.citefactor.org/10.11226/v23i1

Akinnagbe, O.M. and Adonu, A.U. (2014) Rural farmer's source and use of credit in Nsukka local government area of Enugu State, Nigeria. Asian Journal of Agricultural Research, 8(4): 195-203
Journal of Agricultural Extension

Vol. 23 (1) January, 2019

ISSN(e): 24086851; ISSN(Print); 1119944X

http://journal.aesonnigeria.org

http://www.ajol.info/index.php/iae

Email: editorinchief@aesonnigeria.org

Asogwa, R., Barungi, B., Odhiambo, O. and Zerihun, A., (2016) Nigeria 2016. Nigeria Economic Outlook, African Development Bank Group.www.afdb.org/en/countries/west-africa/nigeria-economic-outlook/ Date?

Central Intelligence Agency (CIA) World Fact Book (2016) Nigeria Economy 2016. Available at http://www.theodora.com/wfbcurrent/nigeria/nigeria_economy.html Retrieved, November, 2016.

Chah, J.M., Irohibe, I.J., Itodo, C.I. and Enwelu, I.A., (2015) Information needs of indigenous chicken farmers in Enugu State: Implications for agricultural extension service.British Journal of Applied Science \& Technology, 7(4): 404-411.

Christiansen, Luc. (2017) Agriculture in Africa-Telling Myths from facts: A synthesis Policy Research Working paper; No. 7979, World bank, Washington, DC.

Ifeanyi-Obi, C.C., Togun, A.O., Lamboll, R., and Adesope, O.M. and Arokoyu, S.B. (2017)Challenges faced by cocoyam farmers in adapting to climate change in Southeast Nigeria. Climate Risk Management, 17:155-164 Available at http://dx.doi.org/10. 1016/j.crm. 2017.04.002.Retrieved on 18/6/2017.

John, C. I. and Osondu, K. O., (2015) Agricultural credit sources and determinants of credit acquisition by farmers in Idemili local government area of Anambra State. Journal of Agricultural Science and Technology, 5:34-43.

Mgbakor, M.N.,Uzendu, P.O. and Ndubisi, D.O., (2014) Sources of agricultural credit to small-scale farmers in Ezeagu local government area of Enugu State, Nigeria. Journal of Agriculture and Veterinary Science, 7(8): 01-08. Available at www.iosrjournals.org

Muhammad, H. and Agabi, C. (2016) As Nigeria's economy slips into recession, rising inflation, FX may define MPC meeting. Analysis budget. Available at http://naija247 news.com/2016/07/nigerias-economy-slips-recession-rising-inflation-fx-may-definempc-meeting/ Retrieved on 18/5/2017

Nzeh, E. C., Akogwu, C. I., Ugwu, J. N., and Nzeh, C., (2014) Cost-return analysis of cocoyam marketing in Nsukka agricultural zone of Enugu State, Nigeria.Sky Journal of Agricultural Research, 3(11): 215-222.

Sanzidur, R. and Chidiebere, D.C., (2016) Determinants of food crop diversity and profitability in southeastern Nigeria: A multivariate tobit approach. Agriculture, 6(14): 1-14. doi:10.3390/agriculture6020014 
Creative Commons User License: CC BY-NC-ND

Abstracted by: EBSCOhost, Electronic Journals Se

Google Scholar, Journal Seek, Scientific Commons,

Food and Agricultural Organization (FAO), CABI and Scopus

http://eoi.citefactor.org/10.11226/v23i1
Journal of Agricultural Extension

Vol. 23 (1) January, 2019

ISSN(e): 24086851; ISSN(Print); 1119944X

http://journal.aesonnigeria.org

http://www.ajol.info/index.php/iae

Email: editorinchief@aesonnigeria.org

Sokoya, A.A., Adefunke, O.A. and Fagbola, B. (2014) Farmers information literacy and awareness towards agricultural produce and food security: FADAMA III programs in Osun state Nigeria. Literacy Information and Computer Education Journal, 1(4). Available athttp://creativecommons.org/licenses/by/3.0/Retrieved on 20/6/2017 